\title{
Genetic polymorphisms of vascular endothelial growth factor (VEGF) associated with gastric cancer recurrence after curative resection with adjuvant chemotherapy
}

\author{
Yeon-Ji Kim', Woo Chul/ Chung ${ }^{1 *}$, Kyong-Hwa Jun ${ }^{2}$ and Hyung-Min Chin ${ }^{2}$
}

\begin{abstract}
Background: The relationship between polymorphisms in vascular endothelial growth factor (VEGF) and gastric cancer is still inconclusive. We investigated whether there is an association between VEGF genetic polymorphisms and risk of gastric cancer, and evaluated the recurrence of advanced gastric cancer after curative resection with adjuvant chemotherapy according to VEGF genetic polymorphisms.

Methods: The association of functional single nucleotide polymorphisms (SNPs) of the VEGF gene $(+936 \mathrm{C}>\mathrm{T},-634 \mathrm{G}>\mathrm{C},-2578 \mathrm{C}>\mathrm{A},+1612 \mathrm{G}>\mathrm{A})$ were evaluated. Genotypes were determined by polymerase chain reaction-restriction fragment length polymorphism (PCR-RFLP) analysis. A total of 151 patients with gastric cancer were enrolled, and the control group consisted of 413 individuals with esophagogastroduodenoscopy who were randomly selected through health screening. All of the enrolled patients had curative resections with completion of adjuvant capecitabine and oxaliplatin combination chemotherapy and the initial metastatic cases were excluded. During the regular follow-up protocol, the episodes of the recurrence were documented and the specific genotype and allelic frequencies were evaluated.

Results: As for the cancer risk, there were no significant differences in specific genotypes and allelic frequencies. The mean follow-up period was $28.82 \pm 30.92$ (12 72) months and the recurrence rate was $28.3 \%$. In the patients carrying the $936-C$ allele, the recurrence rate of gastric cancer was high $(P=0.02)$. Disease-free interval was significantly different between the patients carrying the 936-CC and 936-CT/TT genotype ( $P=0.02)$.

Conclusions: VEGF 936-C allele is associated with poor prognosis, but not risk of gastric cancer. In the patients carrying the 936-C allele, more potent adjuvant treatment would be considered.
\end{abstract}

Keywords: VEGF, Polymorphism, Gastric cancer, Prognosis

\footnotetext{
* Correspondence: jwchulkr@catholic.ac.kr

${ }^{1}$ Division of Gastroenterology, Department of Internal Medicine, St. Vincent's

Hospital "The Catholic University of Korea, 93-6 Jungbu-daero, Paldal-gu,

Suwon, Republic of Korea

Full list of author information is available at the end of the article
}

(c) The Author(s). 2019 Open Access This article is distributed under the terms of the Creative Commons Attribution 4.0 International License (http://creativecommons.org/licenses/by/4.0/), which permits unrestricted use, distribution, and reproduction in any medium, provided you give appropriate credit to the original author(s) and the source, provide a link to the Creative Commons license, and indicate if changes were made. The Creative Commons Public Domain Dedication waiver (http://creativecommons.org/publicdomain/zero/1.0/) applies to the data made available in this article, unless otherwise stated. 


\section{Background}

Gastric cancer is the third and fifth-leading cause of cancer-related deaths in men and women, respectively worldwide [1]. Populations in eastern Asia have the highest gastric cancer burden in the world, and this region accounts for more than $60 \%$ of all gastric cancer cases [2]. The occurrence of gastric cancer involves several factors such as genetic, environmental and infectious agents, including Helicobacter pylori, having a cumulative effect in the early steps of gastric carcinogenesis [3].

Angiogenesis, the formation of new blood vessels from pre-existing vasculature is one of the hallmarks of cancer and plays a pivotal role in carcinogenesis by influencing growth, invasion, and metastasis [4]. Vascular endothelial growth factor (VEGF) is considered an important mediator of angiogenesis and an essential factor in cancer development and progression. VEGF promotes formation of new blood vessels, and subsequently enhances vascular permeability of endothelial cells, which are crucial events in cancer formation, invasion and metastasis $[5,6]$. The VEGF gene is located on chromosome 6 p21.3 and consists of 8 exons and 7 introns. It is highly polymorphic, with at least 30 functional single-nucleotide polymorphisms (SNPs) in the $5^{\prime}$-untranslated region (UTR), 3' - UTR, and promoter regions [7]. Particular focus has been on SNPs found in those in regulatory regions because they may alter VEGF expression levels [8]. High VEGF levels are associated with malignancies such as breast, lung, kidney, ovarian, colorectal and stomach cancer [9-15]. Moreover, these increased levels are associated with advanced stages and poor survival in several types of cancer. Hence, VEGF polymorphisms may influence cancer susceptibility.

Several potentially functional SNPs $(-634 \mathrm{G}>\mathrm{C},-7 \mathrm{C}>$ $\mathrm{T},-1498 \mathrm{C}>\mathrm{T},-1154 \mathrm{G}>\mathrm{A},-2578 \mathrm{C}>\mathrm{A}$ and $-2489 \mathrm{C}>\mathrm{T}$ in the promotor or in the $5^{\prime}$-untranslated region (UTR) and $+936 \mathrm{C} 29>\mathrm{T}$ and $+1612 \mathrm{G}>\mathrm{A}$ in the $3^{\prime}$-UTR) have been revealed and might affect the expression of the VEGF gene [16]. It is likely that only a small number of these polymorphisms and haplotypes actually have a functional effect on VEGF translation [17]. Previous studies suggested that $+936 \mathrm{C}>\mathrm{T} \quad(\mathrm{rs3025039}), \quad-634 \mathrm{G}>\mathrm{C}$ (rs2010963), -2578C >A (rs699947), and +1612G > A (rs10434) are common SNPS in the VEGF, and they are reported to have a role in VEGF protein synthesis [18]. Several studies revealed that $2578 \mathrm{C} / \mathrm{A}$, and $634 \mathrm{G} / \mathrm{C}$ genotypes appear to be associated with a higher VEGF expression whereas the $936 \mathrm{~T}$ allele is correlated to lower VEGF expression [19, 20].

Although there are controversies possibly derived from cell-specific effects of VEGF SNPs in the solid tumors, several previous studies reported that VEGF polymorphisms contribute to the development and prognosis of cancers including gastrointestinal cancer as well as lung cancer, breast and urogenital cancer [21-29].
The role of VEGF SNPs in clinical outcomes in patients with gastric cancer was previously studied retrospectively, producing inconclusive results, as there was selection bias for enrollment and a lack of uniform criteria for primary end points [30-34]. To date, here is limited data correlating VEGF polymorphism and the prognosis of gastric cancers.

We aimed to clarify the potential association of four VEGF genetic polymorphisms (+936C $>\mathrm{T},-634 \mathrm{G}>\mathrm{C}$, $-2578 \mathrm{C}>\mathrm{A}$ and $+1612 \mathrm{G}>\mathrm{A}$ ) with gastric cancer risk, and evaluated the recurrence of advanced gastric cancer according to VEGF genotypes.

\section{Methods}

A total of 151 patients with gastric cancer who were operated on at St. Vincent Hospital from January 2010 to January 2013 were enrolled prospectively. The control group comprised 413 healthy individuals with esophago-gastroduodenoscopy who were randomly selected through health screening during the same period of time. Patients eligible for this study were identified preoperatively as having histological gastric adenocarcinoma. They were offered participation, and were required to provide informed consent. Written permission was obtained from all the participants and the study was approved by the Research Ethics Committee of St. Vincent Hospital Affiliated with the Catholic University of Korea (VC09TISI0005).

After curative operation, patients were subjected to adjuvant combination chemotherapy. We treated patients with 3-week cycles of chemotherapy (oral capecitabine $1000 \mathrm{mg} / \mathrm{m}^{2}$ twice daily from the evening of day 1 until the morning of day 15 plus intravenous oxaliplatin $130 \mathrm{mg} / \mathrm{m}^{2}$ on day 1 of each cycle). All patients were well hydrated and standard prophylactic medications were administered to reduce toxic effects. Treatment was continued for 6 months until toxic effects reached our endpoints.

After the adjuvant chemotherapy, a follow-up of all patients was carried out according to our standard protocol (every 3 months for at least 2 years, every 6 months for the following 3 years, and every 12 months after 5 years). The check-up items included physical examination, tumor marker examination, and computed tomographic scans. Endoscopic examination was carried out regularly (every 6 months for at least 2 years, every 12 months for the following years). Recurrent and mortality events were recorded, and disease-free survival (DFS) was calculated for the prognosis assessment.

\section{DNA extraction}

The association of functional SNPs of the VEGF gene with gastric cancer development was evaluated in a case-control study of gastric cancer patients. Peripheral venous blood samples $(3 \mathrm{~mL})$ were acquired from all 
subjects in heparin vacutainers. Genomic DNA was obtained from the peripheral blood lymphocytes of study subjects using the Genomic DNA Extraction Kit (Bioneer Corp., Daejeon, Korea). Genomic DNA was isolated according to the manufacturer's protocol. All samples were collected prior to treatment.

\section{Detection of VEGF gene polymorphism}

The VEGF genotypes were selected from the previous study [8]. The four VEGF genotype polymorphisms $(+936 \mathrm{C}>\mathrm{T}$ (rs3025039), -634G > C (rs2010963), -2578C > A (rs699947), and $+1612 \mathrm{G}>\mathrm{A}$ (rs10434)) were determined by polymerase chain reaction-restriction fragment length polymorphism (PCR-RFLP) methods with PCR primer pairs listed in Table 1 [35-37].

The PCR was carried out in a $30-\mu \mathrm{L}$ reaction mix containing 100 ng DNA template, 1 unit of Taq DNA polymerase (iNtRON Biotechnology, Seoul, Korea), $0.2 \mathrm{mmol} / \mathrm{L}$ deoxyribonucleotide triphosphate (dNTP) ( $\mathrm{pH} 8.3), 0.5 \mu \mathrm{M}$ forward primer, $0.5 \mu \mathrm{M}$ reverse primer, $1 \times \mathrm{PCR}$ buffer with $1.5 \mathrm{mM} \mathrm{MgCl} 2$ and $50 \mathrm{mmol} / \mathrm{LKCl}$.

The PCR reaction was carried out in a thermocycler and reaction conditions consisted of $95^{\circ} \mathrm{C}$ denaturation for $5 \mathrm{~min}, 94^{\circ} \mathrm{C}$ annealing for $30 \mathrm{~s}, 62^{\circ} \mathrm{C}$ annealing for $30 \mathrm{~s}, 72^{\circ} \mathrm{C}$ annealing for $30 \mathrm{~s} \mathrm{(40} \mathrm{cycles)} \mathrm{and} 72{ }^{\circ} \mathrm{C}$ elongation for $10 \mathrm{~min}$. The PCR products were digested with appropriate restriction enzymes (New England BioLabs, Beverly, MA, USA) at $37-65^{\circ} \mathrm{C}$ for $2-16 \mathrm{~h}$. The restriction enzymes were BstY1(2578C/A), MnlI (1612G/A), BsmFI $(634 \mathrm{C} / \mathrm{G})$ and NlaIII $(936 \mathrm{C} / \mathrm{G})$. The PCR and digestion products were analyzed with a $6 \%$ agarose gel with intercalating dye (ethidium bromide) staining. Selected PCR-amplified DNA samples were analyzed by DNA sequencing (Fig. 1).

\section{Statistical analysis}

Unpaired t-test was used for continuous variable such as age. Chi-square test or Fisher's exact test was for genotype frequency and recurrence risk or allele frequency and recurrence risk estimate. Correlation between incidence of cancer, and genotype was evaluated using the chi-squared test, if all cells of the contingency table

Table 1 Specific primers according to four VEGF polymorphisms

\begin{tabular}{ll}
\hline+936 C > T (rs3025039) & 5'-AGG AAG AGG GAC TCT GCG CAG AGC-3' (forward) \\
& 5'-TAA ATG TAT GTA TGT GGG TGG GTG TGT CTA \\
& CAG G-3' (reverse) \\
& 5'- ATT TAT TाT TGC TTG CCA TT - 3'(forward) \\
& 5'- GTC TGT CTG TCT GTC CGT CA - 3'(reverse) \\
-2578 C > A (rs699947) & 5' - GGC CTT AGG ACA CCA TAC C - 3'(forward) \\
& 5'- CAC AGC TTC TCC CCT ATC C - 3'(reverse) \\
+1612 G > A (rs10434) & 5'- CAC ATG CTG CAC GCG CAT CTC A - 3'(forward) \\
& 5'- ACC CCA GGA AGG GGA GCA GGA - 3'(reverse) \\
\hline
\end{tabular}

contained at least 5 elements or Fischer's exact test if the table included small cells. The odds ratio (OR) and confidence interval (CI) values of associations of genotype frequencies were calculated using univariate logistic regression, adjusting for potential confounding factor such as age, gender, smoking status and alcohol ingestion. Kaplan-Meier method was applied to plot survival curves and the statistical differences were analyzed by the log-rank test. All statistical analyses were two-sided, and $P<0.05$ was considered statistically significant. Analyses were performed using SPSS version 19.0.

\section{Results}

There were 94 males and 57 females in the gastric cancer group. The age of patients ranged from 29 to 83 years, with the average age of $66.16 \pm 12.78$ years. The baseline characteristics of gastric cancer patients and individuals of the control group are shown in Table 2.

\section{VEGF polymorphism and risk of gastric cancer}

The four VEGF genotype and allele distribution in the gastric cancer patients and the control subjects are presented in Table 3. All of the VEGF polymorphisms in the case and control patients were consistent with Hardy-Weinberg equilibrium. There were no significant differences in genotype subgroups and the frequencies between gastric cancer group and healthy controls.

\section{Recurrent gastric cancer after curative resection with} adjuvant chemotherapy according to VEGF polymorphism After curative resection, 16 patients were excluded from the study; there was no follow-up performed on 14 patients, one died a non-cancer-related death, and one experienced a fatal post-operative complication. A follow up of $28.82 \pm 30.92(12 \sim 72)$ months in a total of 135 patients with gastric cancer was performed (Table 4).

For the precise prediction of recurrence according to VEGF polymorphisms, we excluded very early gastric cancer (stage IA, 18 patients) and metastatic gastric cancer at the time of initial diagnosis (stage IV, 18 patients). Among remaining 99 patients (Table 5), the recurrence rate was $28.3 \%$ (28/99). Owing to the very small number of patients with the each polymorphism, the two genotypes were grouped together and analyzed dominant genetic model [rs3025039 CC and (CT + TT), rs2010963 GG and (CG + CC), rs699947 CC and (CA + AA rs10434 GG and (AG + AA) in VEGF gene]. Compared with CT or TT genotype, 936-CC didn't have statistical significance in increasing cancer recurrence (OR $0.37, \quad 95 \% \mathrm{CI}=0.13-1.03, \quad P=0.06$, adjust $P=0.9$ ) (Table 6). The frequency of the 936-C allele was significantly higher in the recurrence group $(P=0.02$, adjust $P=0.04$ ) (Table 7). 


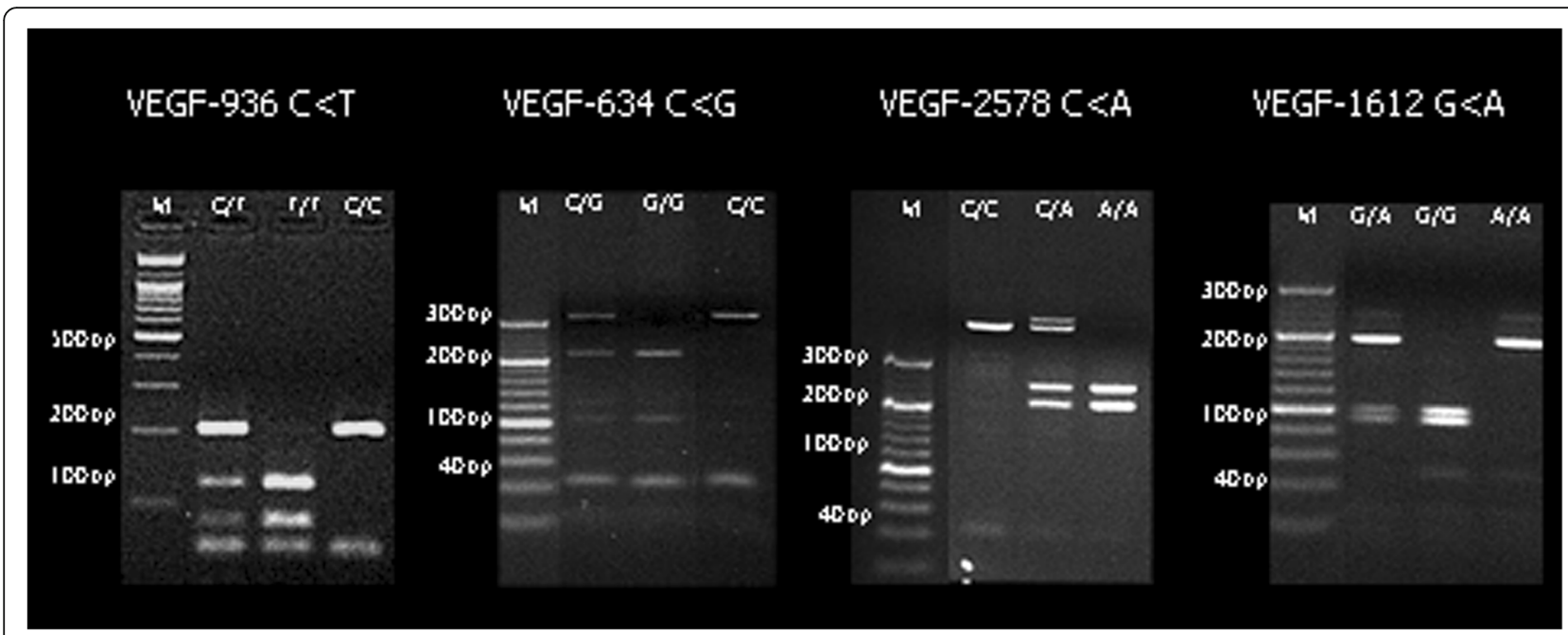

Fig. 1 PCR for VEGF gene polymorphisms

DFS after curative resection with adjuvant chemotherapy according to VEGF polymorphism

The proportion of 936-TT genotype was very small, we grouped 936-TT genotype and 936-CT genotype together and compared their DFS to that of the 936-CC genotype (dominant genetic model). In the patients with VEGF 936-CC genotype and 936-CT/-TT genotypes, DFS intervals were $51.13 \pm 30.20$ months and $62.26 \pm 22.98$ months, respectively. In a Kaplan-Meier survival curve, DFS of the patients with the VEGF 936-CC genotype was significantly lower than that of the others $(P=0.02)$ (Fig. 2).

\section{Discussion}

Surgical resection with D2 lymphadenectomy has been established as standard procedure for non-metastatic advanced gastric cancer. The recurrence of gastric cancer is common, even though $\mathrm{R} 0$ resection was completed at the time of primary treatment. Survival rate depends on the

Table 2 Baseline characteristics of the patients with gastric cancer and controls

\begin{tabular}{llll}
\hline & $\begin{array}{l}\text { Gastric Cancer } \\
N=151\end{array}$ & $\begin{array}{l}\text { Non-cancer } \\
\text { Control N=413 }\end{array}$ & P-value \\
\hline Sex (Male: Female) & $94: 57$ & $250: 163$ & 0.71 \\
Age & $66.16 \pm 12.78$ & $51.45 \pm 12.24$ & $0.01^{*}$ \\
Current smoker & 45 & 152 & 0.12 \\
Current alcohol drinker & 48 & 160 & 0.13 \\
Initial stage & IA (20) IB (37) & \\
& IIA (16) IIB (22) & \\
& IIIA (10) IIIB (14) IIIC (14) & \\
& IV (18) & & \\
\hline
\end{tabular}

*value means that the $p$-value is significant stage of the cancer at the time of diagnosis; unfortunately survival rate after 5 years is below $30 \%$ in most patients with advanced gastric cancer. In clinical practice guidelines for gastric cancer treatment in Korea, adjuvant chemotherapy with either S-1 monotherapy or capecitabine and oxaliplatin combination therapy can be recommended after surgery for gastric cancer. Although the adoption of adjuvant chemotherapy after curative resection has been clear beneficial for recurrence and survival, new additional treatments are needed to increase the survival rate.

VEGF is a critical angiogenic factor that regulates capillary formation, vascular permeability, and endothelial cell proliferation, migration and differentiation. Several genotypes of VEGF polymorphisms influence VEGF production and are associated with susceptibility or severity of many diseases, including cancer. Previous studies suggested the association between VEGF polymorphism and risk of cancer, but the results remained inconclusive [30, 31, 38-40]. Particularly, in gastric cancer, several meta-analysis showed that there were debatable results [32-34, 41-46].

In the Chinese Han race and Japanese study, VEGF + $1612 \mathrm{G}>\mathrm{A}$ gene polymorphism was found to be possibly associated with gastric cancer [34, 47]. A meta-analysis including these studies showed the 1612 A allele was a recessive gastric cancer susceptibility allele with a $60 \%$ increase of risk [37]. Recent meta-analysis showed + 1612 G/A G allele may decrease the gastric cancer risk in the Asian population $[45,46]$. Some studies were examined for the relationship between cancer risk and - 2578 $\mathrm{C}>\mathrm{T}$ and $-634 \mathrm{G}>\mathrm{C}$ polymorphism $[34,48,49]$. In the Greek population, $-2578 \mathrm{C}>\mathrm{A}$ and $-634 \mathrm{G}>\mathrm{C}$ polymorphism were associated with larger tumor size, poor differentiation, advanced stage of gastric cancer [48]. However, 
Table 3 Comparison of genotype frequencies of the four polymorphisms according to the presence or absence of gastric cancer

\begin{tabular}{|c|c|c|c|c|c|c|c|}
\hline \multirow{2}{*}{$\frac{\text { VEGF SNP }}{-936 \mathrm{C}>\mathrm{T}}$} & \multicolumn{3}{|c|}{ Gastric Cancer $N=151(\%)$} & \multicolumn{3}{|c|}{ Non-cancer Control N=413 (\%) } & \multirow{2}{*}{$\frac{P \text {-value }}{0.88}$} \\
\hline & CC & $C T$ & $\pi$ & $\mathrm{CC}$ & CT & $\pi$ & \\
\hline & 98 & 48 & 5 & 258 & 141 & 14 & \\
\hline & $(64.9)$ & $(31.8)$ & (3.3) & $(62.5)$ & $(34.1)$ & (3.4) & \\
\hline \multirow[t]{3}{*}{$-634 C>G$} & CC & CG & GG & $\mathrm{CC}$ & CG & GG & 0.80 \\
\hline & 28 & 70 & 53 & 59 & 178 & 130 & \\
\hline & $(18.5)$ & $(46.4)$ & $(35.1)$ & $(14.4)$ & $(43.1)$ & $(31.5)$ & \\
\hline \multirow[t]{3}{*}{$-2578 C>A$} & $\mathrm{CC}$ & CA & $A A$ & CC & CA & AA & 0.15 \\
\hline & 82 & 53 & 16 & 236 & 150 & 27 & \\
\hline & (54.3) & $(35.1)$ & (10.6) & $(57.1)$ & (36.3) & $(6.6)$ & \\
\hline \multirow[t]{3}{*}{$-1612 G>A$} & GG & $A G$ & AA & GG & GA & AA & 0.35 \\
\hline & 102 & 43 & 6 & 308 & 93 & 12 & \\
\hline & (67.5) & $(28.5)$ & (4.0) & (74.6) & (22.5) & (2.9) & \\
\hline
\end{tabular}

Chinese study didn't revealed association these two SNP and the gastric cancer risk [49]. Meta-analyasis revealed that VEGF- $2578 \mathrm{C}>\mathrm{A}$ gene polymorphisms were found to be unassociated with gastric cancer risk, whereas the VEGF-634 G > C GG genotype was associated with gastric cancer risk [45].

In the Korean population, there is significant association of $\mathrm{T}$ allele-bearing genotypes with increased risk for stomach cancer development, which suggests that the VEGF $+936 \mathrm{C}>\mathrm{T}$ polymorphism is a susceptibility [47]. In a meta-analysis, there was no association between VEGF + $936 \mathrm{C}>\mathrm{T}$ polymorphism and gastric cancer risk; 4 from Asian populations and 3 Caucasian populations [32]. In addition, a meta-analysis analysis of polymorphisms from only Asian populations showed that the VEGF $+936 \mathrm{C}>\mathrm{T}$ polymorphism is not associated with risk of overall cancer $[44,45]$. In the present study, we investigated the association between four VEGF gene polymorphisms and gastric cancer risk and

Table 4 Comparison of genotype frequencies of the four polymorphisms according to patients prognosis associated with metastasis and recurrence

\begin{tabular}{|c|c|c|c|c|c|c|c|c|}
\hline \multirow{2}{*}{$\begin{array}{l}\text { VEGF SNP } \\
-936 C>T\end{array}$} & \multicolumn{3}{|c|}{$\begin{array}{l}\text { Gastric cancer } \\
\text { after curative } \\
\text { surgery }(N=89)\end{array}$} & \multicolumn{3}{|c|}{$\begin{array}{l}\text { Initial metastasis } \\
(N=18) / \text { Recurrence } \\
\text { after resection } \\
(N=28)\end{array}$} & \multicolumn{2}{|l|}{$P$-value } \\
\hline & CC & $C T$ & $\pi$ & CC & $C T$ & $\pi$ & 0.30 & \\
\hline & 57 & 30 & 2 & 35 & 10 & 1 & & 44.37813 \\
\hline \multirow[t]{2}{*}{$-634 C>G$} & CC & CG & GG & CC & CG & GG & 0.91 & \\
\hline & 19 & 45 & 25 & 9 & 25 & 12 & & \\
\hline \multirow[t]{2}{*}{$-2578 C>A$} & CC & CA & $\mathrm{AA}$ & CC & $C A$ & $\mathrm{AA}$ & 0.86 & \\
\hline & 50 & 30 & 9 & 28 & 14 & 4 & & \\
\hline \multirow[t]{2}{*}{$-1612 G>A$} & GG & $A G$ & AA & GG & GA & $\mathrm{AA}$ & 0.72 & \\
\hline & 64 & 21 & 4 & 30 & 14 & 2 & & \\
\hline
\end{tabular}

found that there were no significant differences in specific genotypes for gastric cancer risk.

Since VEGF has become a potential therapeutic target in the treatment of cancer, studies regarding its polymorphisms would be a basis for genetic tailored therapy in the near future [50]. As previously shown, the specific genotype of VEGF $+936 \mathrm{C}>\mathrm{T}$ might be an important determinant of VEGF plasma levels, which were closely relevant to lymph node metastasis [51, 52]. Although the polymorphism has been shown to affect the expression of the VEGF gene, the results remain inconclusive. Currently, there are a limited number of studies regarding VEGF gene polymorphisms and gastric cancer prognosis [30, 31, 53]. In a large-scale study, the VEGF 936-TT genotype was correlated with a worse overall survival compared with the VEGF 936-CC genotype [30]. However, more than $50 \%$ of patients had stage 0 or I early gastric cancers, and $8.4 \%$ had stage IV advanced gastric cancers. Only,

Table 5 Baseline characteristics of patients with gastric cancer except stage IA and IV

\begin{tabular}{llll}
\hline & $\begin{array}{l}\text { Gastric cancer } \\
\text { after curative } \\
\text { surgery } N=71\end{array}$ & $\begin{array}{l}\text { Recurrence } \\
\text { after resection } \\
N=28\end{array}$ & P-value \\
\hline Sex (Male: Female) & $50: 21$ & $22: 6$ \\
Age & $58.99 \pm 11.92$ & $62.89 \pm 12.01$ & 0.14 \\
Current smoker & 22 & 7 & \\
Current alcohol & 20 & 10 & \\
drinker & & & \\
Chemotherapy & 70 & 28 \\
Initial stage & IB (33) & IIA (5) IIB (5) \\
& IIA (8) IIB (14) & IIIA (4) IIIB (7) IIIC (7) &
\end{tabular}


Table 6 Comparison of genotype frequencies of the four polymorphisms according to gastric cancer recurrence after surgery

\begin{tabular}{|c|c|c|c|c|c|}
\hline \multicolumn{2}{|l|}{ VEGF SNP } & \multirow[t]{2}{*}{$\begin{array}{l}\text { Advanced Gastric } \\
\text { Cancer after curative } \\
\text { resection }(N=71)\end{array}$} & \multirow[t]{2}{*}{$\begin{array}{l}\text { Recurrence after } \\
\text { resection }(N=28)\end{array}$} & \multirow{2}{*}{$\begin{array}{l}P \text {-value (adjust) } \\
0.06(0.09)\end{array}$} & \multirow[t]{2}{*}{ OR $(95 \% \mathrm{Cl})$} \\
\hline$-936 C>T$ & & & & & \\
\hline Dominant $C C$ vs $C T+\Pi$ & $\mathrm{CC}$ & 41 & 22 & & 1.0 \\
\hline 1 & $C T+\pi$ & 30 & 6 & & $0.37(0.13-1.03)$ \\
\hline$-634 C>G$ & & & & $0.75(0.94)$ & \\
\hline \multirow[t]{2}{*}{ Dominant GG vs CG + CC } & GG & 23 & 10 & & 1.0 \\
\hline & $C G+G G$ & 48 & 18 & & $0.86(0.34-2.16)$ \\
\hline$-2578 C>A$ & & & & $0.79(0.97)$ & \\
\hline \multirow[t]{2}{*}{ Dominant CC vs CA + AA } & CC & 41 & 17 & & 1.0 \\
\hline & $C A+A A$ & 30 & 11 & & $0.88(0.36-2.16)$ \\
\hline$-1612 \mathrm{G}>\mathrm{A}$ & & & & $0.46(0.62)$ & \\
\hline \multirow[t]{2}{*}{ Dominant GG vs GA + AA } & GG & 51 & 18 & & 1.0 \\
\hline & $\mathrm{GA}+\mathrm{AA}$ & 20 & 10 & & $1.42(0.56-3.59)$ \\
\hline
\end{tabular}

NOTE: Adjusted for age, gender, smoking status, and alcohol ingestion

$\mathrm{Cl}$ confidence interval, $O R$ odds ratio

$33.4 \%(167 / 500)$ of patients received adjuvant chemotherapy with different regimens. Therefore, a selection bias was present and may have resulted in an inaccurate conclusion. In another study, the VEGF - 634G > C polymorphism was related to poor clinical outcome in advanced gastric cancer patients with chemotherapy [31]. However, more than $50 \%$ of patients (113/ 190) had stage IV advanced gastric cancer and only $41.6 \%(79 / 190)$ of patients received chemotherapy with FOLFOX. In the study on the risk for gastric cancer development and prognostic characteristics, there was a relation between the VEGF 936-TT genotype and poor prognosis. Stage I (18\%) and stage IV (25\%) patients were enrolled, and the primary end point was survival time without individual treatment protocol [53].

This study will help strengthen the knowledge on association of VEGF gene polymorphisms with

Table 7 Comparison of allele frequencies of the four polymorphisms according to gastric cancer recurrence after surgery

\begin{tabular}{|c|c|c|c|c|c|}
\hline VEGF SNP & & $\begin{array}{l}\text { Advanced Gastric Cancer after } \\
\text { curative resection }(N=71)\end{array}$ & $\begin{array}{l}\text { Recurrence after } \\
\text { resection }(N=28)\end{array}$ & $P$-value (adjust) & OR $(95 \% \mathrm{Cl})$ \\
\hline \multirow[t]{4}{*}{$-936 C<T$} & & & & $0.02^{*}$ & \\
\hline & & & & $(0.04)$ & \\
\hline & C allelic frequency & $77.5 \%$ & $89.3 \%$ & & 1.0 \\
\hline & T allelic frequency & 22.5 & 10.7 & & $0.41(0.19-.91)$ \\
\hline \multirow[t]{4}{*}{$-634 C<G$} & & & & 0.21 & \\
\hline & & & & $(0.27)$ & \\
\hline & $\mathrm{C}$ allelic frequency & 44.4 & 35.7 & & 1.0 \\
\hline & G allelic frequency & 55.6 & 64.3 & & $1.44(0.81-2.53)$ \\
\hline \multirow[t]{4}{*}{$-2578 C<A$} & & & & 0.72 & \\
\hline & & & & $(0.84$ & \\
\hline & C allelic frequency & 74.6 & 76.8 & & 1.0 \\
\hline & A allelic frequency & 25.4 & 23.2 & & $0.89(0.46-1.69)$ \\
\hline \multirow[t]{4}{*}{$-1612 G<A$} & & & & 0.53 & \\
\hline & & & & $(0.66)$ & \\
\hline & G allelic frequency & 83.8 & 80.4 & & 1.0 \\
\hline & A allelic frequency & 16.2 & 19.6 & & $1.26(0.61-2.61)$ \\
\hline
\end{tabular}

* value means that the $p$-value is significant

$\mathrm{Cl}$ confidence interval, $\mathrm{OR}$ odds ratio 


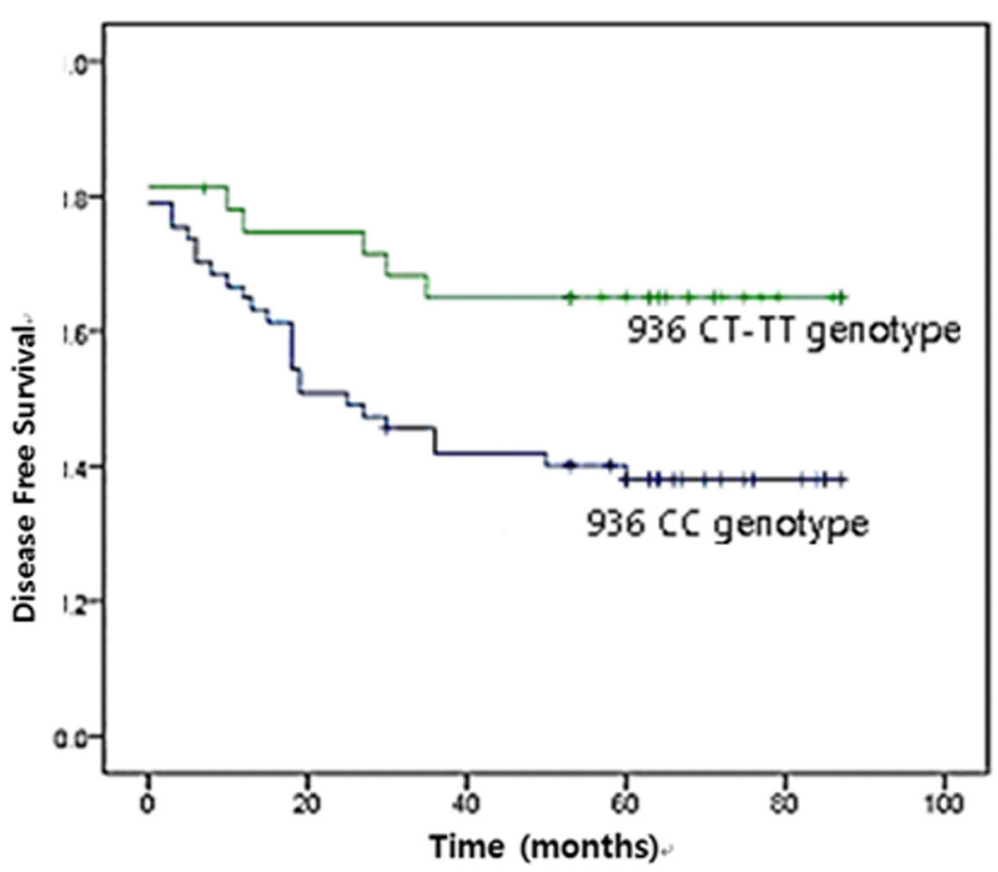

Fig. 2 Kaplan-Meier curve according to VEGF 936-CC and 936-CT/- $\Pi$ genotypes. $(P=0.02)$

gastric cancer prognosis for several reasons. Prospective designed study could eliminate a selection bias, and the exclusion of early mucosal cancer and initially metastatic cases gives a more refined study design. All patients underwent standard surgery with adjuvant chemotherapy and follow-up protocol according to clinical practice guidelines of Korea. In our results, the patients carrying VEGF 936-C allele showed higher recurrence rate of gastric cancer. Additionally, the VEGF 936-CC genotype was correlated with a lower DFS interval than the other genotypes.

Although the results on VEGF $+936 \mathrm{C}>\mathrm{T}$ polymorphism were ambiguous in gastric cancer, recently, similar results in other kind of cancers were reported. In a polymorphism study on non-small cell lung cancer, there was a correlation between the VEGF 936-TT genotype and lower risk of death compared to that with the CC genotype [54]. The VEGF 936-TT genotype played a protective role in the development of differentiated thyroid cancer [55].

This study had several limitations for the interpretation of results. First, the effect of gastric carcinogens such as Helicobacter pylori infection was not taken into consideration. Second, the relatively small sample size might not represent the entire general population. Furthermore, a relatively small number of patients carrying the VEGF $936 \mathrm{~T}$ allele would influence the results.

\section{Conclusions}

In conclusion, our study suggests that the VEGF gene $936+C>T$ polymorphism may be an independent prognostic marker in Korean gastric cancer patients. To improve the prognosis of gastric cancer, the analysis of VEGF gene polymorphisms may help identify a high-risk patient, and help clinicians and patients to seek active treatment.

\section{Abbreviations}

Cl: Confidence interval; DFS: Disease-free survival; dNTP: Deoxyribonucleotide triphosphate; OR: Odds ratio; PCR-RFLP: Polymerase chain reaction-restriction fragment length polymorphism; SNPs: Single nucleotide polymorphisms;

UTR: Untranslated region; VEGF: Vascular Endothelial Growth Factor

\section{Acknowledgements}

We would like to thank Editage [http://www.editage.com/] for English language editing.

\section{Funding}

All authors declare that they have no financial ties to disclose.

\section{Availability of data and materials}

The datasets used during the current study are available from the corresponding author on reasonable request.

\section{Authors' contributions}

Study Conception: WCC. Revision of study design and protocol: WCC, YJK. Study coordination: WCC, YJK, KHJ, HMC. All authors read and approved the final manuscript.

\section{Ethics approval and consent to participate}

This study was approved by the institutional review board at St. Vincent Hospital (VC09TISI0005) and was conducted in accordance with the guidelines of the Declaration of Helsinki for biomedical research. Informed written consent was obtained from all participants. 


\section{Consent for publication}

Not applicable.

\section{Competing interests}

The authors declare that they have no competing interests.

\section{Publisher's Note}

Springer Nature remains neutral with regard to jurisdictional claims in published maps and institutional affiliations.

\section{Author details}

'Division of Gastroenterology, Department of Internal Medicine, St. Vincent's Hospital, The Catholic University of Korea, 93-6 Jungbu-daero, Paldal-gu, Suwon, Republic of Korea. ${ }^{2}$ Department of Surgery, St. Vincent's Hospital, The Catholic University of Korea, 93-6 Jungbu-daero, Paldal-gu, Suwon, Republic of Korea.

Received: 31 January 2018 Accepted: 10 May 2019

Published online: 22 May 2019

\section{References}

1. Jemal A, Bray F, Center MM, Ferlay J, Ward E, Forman D. Global cancer statistics. CA Cancer J Clin. 2011;61:69-90.

2. $\mathrm{Wu} C Y$, Lin JT. The changing epidemiology of Asian digestive cancers: From etiologies and incidences to preventive strategies. Best Pract Res Clin Gastroenterol. 2015:29:843-53.

3. Corso G, Seruca R, Roviello F. Gastric cancer carcinogenesis and tumor progression. Ann Ital Chir. 2012;83:172-6.

4. Wang Z, Dabrosin C, Yin X, Fuster MM, Arreola A, Rathmell WK, et al. Broad targeting of angiogenesis for cancer prevention and therapy. Semin Cancer Biol. 2015;35 Suppl:S224-43.

5. Kammerer PW, Toyoshima T, Eletr S, Kämmerer P, Kuhr K, Al-Nawas B, Brieger J. Single nucleotide polymorphisms of the vascular endothelial growth factor gene associated with incidence of oral squamous cell carcinoma. J Oral Pathol Med. 2010;39:786-92.

6. Yang PW, Hsieh MS, Huang YC, Hsieh CY, Chiang TH, Lee JM. Genetic variants of EGF and VEGF predict prognosis of patients with advanced esophageal squamous cell carcinoma. PLoS One. 2014;9:e100326.

7. Vincenti V, Cassano C, Rocchi M, Persico G. Assignment of the vascular endothelial growth factor gene to human chromosome 6p21.3. Circulation. 1996;93:1493-5.

8. Liu W, Dong Z, Hu R, Wang C. Association of Vascular Endothelial Growth Factor (VEGF) Gene Polymorphisms With Gastric Cancer and Its Development, Prognosis, and Survival. Technol Cancer Res Treat. 2018;17: 1533034617753810.

9. Jin Q, Hemminki K, Enquist K, Lenner P, Grzybowska E, Klaes R, et al. Vascular endothelial growth factor polymorphisms in relation to breast cancer development and prognosis. Clin Cancer Res. 2005;11:3647-53.

10. Yu W, Jiang X, Bai T, Lv X, Chang F. Association between +936 C>T gene polymorphism of vascular endothelial growth factor and lung cancer: a meta-analysis. Cancer Biomark. 2014;14:483-92.

11. Koukourakis MI, Papazoglou D, Giatromanolaki A, Bougioukas G, Maltezos E, Sivridis E. VEGF gene sequence variation defines VEGF gene expression status and angiogenic activity in non-small cell lung cancer. Lung Cancer. 2004:46:293-8

12. Delongchamps NB, Peyromaure $M$. The role of vascular endothelial growth factor in kidney and prostate cancer. Can J Urol. 2007;14:3669-77.

13. Cooper BC, Ritchie JM, Broghammer CL, Coffin J, Sorosky Jl, Buller RE, et al. Preoperative serum vascular endothelial growth factor levels: significance in ovarian cancer. Clin Cancer Res. 2002;8:3193-7.

14. Alabi AA, Suppiah A, Madden LA, Monson JR, Greenman J. Preoperative serum vascular endothelial growth factor-a is a marker for subsequent recurrence in colorectal cancer patients. Dis Colon Rectum. 2009;52:993-9.

15. Konno H, Ohta M, Baba M, Suzuki S, Nakamura S. The role of circulating IL-8 and VEGF protein in the progression of gastric cancer. Cancer Sci. 2003;94:735-40.

16. Jain L, Vargo CA, Danesi R, Sissung TM, Price DK, Venzon D, et al. The role of vascular endothelial growth factor SNPs as predictive and prognostic markers for major solid tumors. Mol Cancer Ther. 2009 Sep;8(9):2496-508.

17. Pander J, Gelderblom H, Guchelaar HJ. Pharmacogenetics of EGFR and VEGF inhibition. Drug Discov Today. 2007 Dec;12(23-24):1054-60.
18. Maeda A, Nakata M, Yasuda K, Yukawa T, Saisho S, Okita R, et al. Influence of vascular endothelial growth factor single nucleotide polymorphisms on non-small cell lung cancer tumor angiogenesis. Oncol Rep. 2013;29:39-44.

19. Maeda A, Nakata M, Yasuda K, Yukawa T, Saisho S, Okita R, et al. Influence of vascular endothelial growth factor single nucleotide polymorphisms on nonsmall cell lung cancer tumor angiogenesis. J Am Soc Nephrol. 2002:13:260-4.

20. Krippl P, Langsenlehner U, Renner W, Yazdani-Biuki B, Wolf G, Wascher TC, et al. A common $936 \mathrm{C} / \mathrm{T}$ gene polymorphism of vascular endothelial growth factor is associated with decreased breast cancer risk. Int J Cancer. 2003;106:468-71.

21. Yamamori M, Sakaeda T, Nakamura T, Okamura N, Tamura T, Aoyama N, et al. Association of VEGF genotype with mRNA level in colorectal adenocarcinomas. Biochem Biophys Res Commun. 2004;325:144-50.

22. Zhao Z, Ba C, Wang W, Wang X, Xue R, Wu X. Vascular endothelial growth factor (VEGF) gene polymorphisms and colorectal cancer: a meta-analysis of epidemiologic studies. Genet Test Mol Biomarkers. 2012;16:1390-4.

23. Song N, Liu B, Wu J, Zhang R, Duan L, He W, et al. Vascular endothelial growth factor (VEGF) -2578C/a and -460C/T gene polymorphisms and lung cancer risk: a meta-analysis involving 11 case-control studies. Tumour Biol. 2014;35:859-70

24. Koukourakis MI, Papazoglou D, Giatromanolaki A, Bougioukas G, Maltezos E. Sivridis E. VEGF gene sequence variation defines VEGF gene expression status and angiogenic activity in non-small cell lung cancer. Lung Cancer. 2004 Dec;46(3):293-8.

25. Yang $Y$, Zhang $X$, Song $D$, Wei J. Association between vascular endothelial growth factor gene polymorphisms and bladder cancer risk. Mol Clin Oncol. 2014:2:501-5.

26. Steffensen KD, Waldstrøm M, Brandslund I, Jakobsen A. The relationship of VEGF polymorphisms with serum VEGF levels and progression-free survival in patients with epithelial ovarian cancer. Gynecol Oncol. 2010 Apr;117(1): 109-16.

27. Tung MC, Hsieh MJ, Wang SS, Yang SF, Chen SS, Wang SW, et al. Associations of VEGF-C genetic polymorphisms with urothelial cell carcinoma susceptibility differ between smokers and non-smokers in Taiwan. PLoS One. 2014;9(3):e91147.

28. Frezzetti D, Gallo M, Maiello MR, D'Alessio A, Esposito C, Chicchinelli N, et al. VEGF as a potential target in lung cancer. Expert Opin Ther Targets. 2017; 21(10):959-66.

29. Liu X, Guan Y, Zhang W, Liu S, Liu J, Wang L, et al. Predictors of recurrence in breast cancer subtypes with negative lymph node in a Chinese population. Int J Clin Exp Pathol. 2014;7:3202-12.

30. Kim JG, Sohn SK, Chae YS, Cho YY, Bae HI, Yan G, et al. Vascular endothelial growth factor gene polymorphisms associated with prognosis for patients with gastric cancer. Ann Oncol. 2007;18:1030-6.

31. Song $Y$, Yang Y, Liu L, Liu X. Association between five polymorphisms in vascular endothelial growth factor gene and urinary bladder cancer risk: A systematic review and meta-analysis involving 6671 subjects. Gene. 2019; 698:186-97.

32. Zhou Y, Hu W, Zhuang W, Liu GJ, Wu TX, Yao X, et al. Vascular endothelial growth factor (VEGF) +936 C/T gene polymorphisms and gastric cancer risk: a meta-analysis involving 4,138 subjects. Int J Biol Markers. 2010;25:213-8.

33. Li A, Gao P, Wang Z, Song Y, Xu Y, Miao Y, et al. Positive association of the vascular endothelial growth factor-a +405 GG genotype and poor survival in stage I-II gastric cancer in the northern Chinese population. Mol Biol Rep. 2013:40:2741-8

34. Zhou Y, Li N, Zhuang W, Wu X. Vascular endothelial growth factor (VEGF) gene polymorphisms and gastric cancer risk in a Chinese Han population. Mol Carcinog. 2011;50:184-8.

35. Elito J Jr, Daher S, Fernandes da Silva MO, Marconi NM, Pendeloski KP, Moron AF, et al. Association study of vascular endothelial growth factor and polymorphisms of its gene with ectopic pregnancy. Am J Reprod Immunol. 2010;63(2):120-5.

36. Tahara T, Arisawa T, Shibata T, Nakamura M, Yamashita H, Yoshioka D, et al. Effect of polymorphisms in the 3'-untranslated region (3'-UTR) of VEGF gene on gastric pre-malignant condition. Anticancer Res. 2009;29(2):485-9.

37. Hong TT, Cai DY, Wu XH, Hua D. Three vascular endothelial growth factor polymorphisms $(-460 \mathrm{C}>\mathrm{T},-2578 \mathrm{C}>\mathrm{a}, 1612 \mathrm{G}>\mathrm{a})$ with cancer risk: a meta-analysis based on 30 case-control studies. Cancer Investig. 2011 Aug;29(7):472-7.

38. Maeda K, Kang SM, Ogawa M, Onoda N, Sawada T, Nakata B, et al. Combined analysis of vascular endothelial growth factor and platelet- 
derived endothelial cell growth factor expression in gastric carcinoma. Int J Cancer. 1997;74:545-50.

39. Wang $X$, Chen $X$, Fang J, Yang C. Overexpression of both VEGF-A and VEGF$C$ in gastric cancer correlates with prognosis, and silencing of both is effective to inhibit cancer growth. Int J Clin Exp Pathol. 2013;6:586-97.

40. Oh SY, Kwon HC, Kim SH, Lee S, Lee JH, Hwang JA, et al. The relationship of vascular endothelial growth factor gene polymorphisms and clinical outcome in advanced gastric cancer patients treated with FOLFOX: VEGF polymorphism in gastric cancer. BMC Cancer. 2013;13:43.

41. Zhou LP, Luan H, Dong XH, Jin GJ, Man DL, Shang H. Vascular endothelial growth factor $+936 \mathrm{C} / \mathrm{T}$ polymorphism and gastric cancer risk: a metaanalysis. Exp Ther Med. 2011;2:931-6.

42. Liu H, Wang S, Huang C. VEGFA+936C/T and -634G/C polymorphisms and gastric cancer risk: a meta-analysis. Asian Pac J Cancer Prev. 2011;12:1979-83.

43. Zhang $C_{1}$ Li JP, Zhou P. Vascular endothelial growth factor (VEGF) $+936 \mathrm{C} / \mathrm{T}$ gene polymorphism and gastric cancer risk: appraisal of a recent metaanalysis. Int J Biol Markers. 2011;26:274-5.

44. Liu XL, Yang QF, Kong BH. Vascular endothelial growth factor $+936 \mathrm{C} / \mathrm{T}$ polymorphism and cancer risk in Asians: a meta-analysis. Genet Mol Res. 2013;12:1924-33

45. Liu W, Dong Z, Hu R, Wang C. Association of Vascular Endothelial Growth Factor (VEGF) Gene Polymorphisms With Gastric Cancer and Its Development, Prognosis, and Survival. Technol Cancer Res Treat. 2018;17:1-8.

46. Zhuang M, Peng Z, Wang J, Su X. Vascular endothelial growth factor gene polymorphisms and gastric cancer risk: a meta-analysis. J BUON. 2017;22(3): 714-24.

47. Tahara T, Shibata T, Nakamura M, Yamashita H, Yoshioka D, Hirata I, et al. Effect of polymorphisms in the 3' untranslated region (3'-UTR) of vascular endothelial growth factor gene on gastric cancer and peptic ulcer diseases in Japan. Mol Carcinog. 2009;48:1030-7.

48. Tzanakis N, Gazouli M, Rallis G, Giannopoulos G, Papaconstantinou I, Theodoropoulos $\mathrm{G}$, et al. Vascular endothelial growth factor polymorphisms in gastric cancer development,prognosis, and survival. J Surg Oncol. 2006; 94(7):624-30.

49. Ke Q, Liang J, Wang LN, Hu ZB, Jin GF, Zhou Y, et al. Potentially functional polymorphisms of the vascular endothelial growth factor gene and risk of gastric cancer. Mol Carcinog. 2008;47(8):647-51.

50. Ferrara N, Gerber HP, LeCouter J. The biology of VEGF and its receptors. Nat Med. 2003;9:669-76

51. Renner W, Kotschan S, Hoffmann C, Obermayer-Pietsch B, Pilger E. A common $936 \mathrm{C} / \mathrm{T}$ mutation in the gene for vascular endothelial growth factor is associated with vascular endothelial growth factor plasma levels. J Vasc Res. 2000;37:443-8.

52. Kim SE, Shim KN, Jung SA, Yoo K, Lee JH. The clinicopathological significance of tissue levels of hypoxia-inducible factor-1alpha and vascular endothelial growth factor in gastric cancer. Gut Liver. 2009:3:88-94.

53. Bae SJ, Ahn DH, Hong SP, Kang H, Hwang SG, Oh D, et al. Gender-specific association between polymorphism of vascular endothelial growth factor (VEGF 936C >T) gene and patients with stomach cancer. Yonsei Med J. 2008; 49:783-91.

54. Chen N, Ma CN, Zhao M, Zhang YJ. Role of VEGF gene polymorphisms in the clinical outcome of non-small cell lung cancer. Genet Mol Res. 2015;14: 16006-11.

55. Kilic I, Guldiken S, Sipahi T, Palabiyik O, Akker M, Celik O, et al. Investigation of VEGF and IL-8 Gene Polymorphisms in Patients with Differentiated Thyroid Cancer. Clin Lab. 2016;62:2319-25.

Ready to submit your research? Choose BMC and benefit from:

- fast, convenient online submission

- thorough peer review by experienced researchers in your field

- rapid publication on acceptance

- support for research data, including large and complex data types

- gold Open Access which fosters wider collaboration and increased citations

- maximum visibility for your research: over $100 \mathrm{M}$ website views per year

At BMC, research is always in progress.

Learn more biomedcentral.com/submissions 